\title{
UPAYA PENANGANAN KORBAN DAN PENCEGAHAN TINDAK PERDAGANGAN ORANG (HUMAN TRAFFICKING) DI KABUPATEN INDRAMAYU PROVINSI JAWA BARAT ${ }^{6}$
}

\author{
Antik Bintari ${ }^{67}$ \\ Nina Djustiana ${ }^{68}$ \\ e-mail: antikiswg-
}

\begin{abstract}
ABSTRAK
Kejahat anperdaganganorang(humantrafficking) adalahkejahat ankemanusiaan yang terorganisasi, artinya kejahat an ini melibatkan beberapa orang yang memiliki jaringan at au keterkaitan satu sama lain dan memiliki tujuan unt uk mengeksploitasi korban demi keuntungan sepihak (pelaku). Dalam kurun waktu 2005-2009, Jawa Barat menduduki peringkat teratas kasus human trafficking. Salah satu daerah di Provinsi Jawa Barat yang merupakan daerah rentan menghadapi permasalahan tindak human trafficking adalah Kabupaten Indramayu. Berbagai data menyebutkan bahwa kasus humantrafiking di Kabupaten Indramayu selalumengalami peningkatan setiap tahunnya. Penelitian kali ini mencoba menghadirkan hal-hal yang telah dan akan dilakukan oleh stakeholder di Kabupaten Indramayu dalam meminimalisasi tingkat tindak human trafficking.
\end{abstract}

Kata Kunci: eksploitasi, perdagangan orang.

\section{ABSTRACT}

The crime of human trafficking is an organized crime against humanity, that involves several people who have a network or connection to each other and have a goal to exploit the victim for the benefit of unilateral (actors). In the period 20052009, West Java is the highest rank to the case of human trafficking in Indonesia. District Indramayu is one area in West Java province which is a prone area of

66 Penelitian ini didanai oleh Badan Pemberdayaan Perempuan dan Keluarga Berencana (BPPKB) Provinsi Jawa Barat Tahun 2011

67 Dosen Program Studi Ilmu Pemerintahan FISIP Unpad dan Sekretaris Puslitbang Gender dan Anak LPPM Unpad

68 Dosen FKG Unpad dan Kepala Puslitbang Gender dan Anak LPPM Unpad

124 | CosmoGov, Vol.1 No.1, April 2015 
human trafficking cases. According to various datas, we get some fatcs that human trafficking cases in Indramayu incrased annualy. This research tries to present all that have been and will be carried out by stakeholders in District Indramayu in minimizing the level of acts of human trafficking.

Keywords : exploitation, human trafficking.

\section{PENDAHULUAN}

Kasus perdagangan orang (human trafficking, selanjutnya cukup ditulis dengantrafficking) di Indonesia sungguh kian mengkhawatirkan. Dari tahun ke tahun, kasus ini meningkat tajam. Seakan-akan, kasus trafficking di Indonesia diibaratkan gunung es. Artinya, angka yang tersembunyi di bawah permukaan jauh lebih besar ketimbang yang terlihat di permukaan. Data dari International Organization for Migration (IOM) mencat at hingga April 2006 bahwa jumlah kasus trafficking di Indonesia mencapai 1.022 kasus, dengan rinciannya: $88,6 \%$ korbannya adalah perempuan, $52 \%$ dieksploitasi sebagai pekerja rumah tangga, dan $17,1 \%$ dipaksa melacur (www.bkkbn.go.id). Kejahatan trafficking adalah kejahatan yang terorganisasi, artinya kejahat an ini melibatkan beberapa orang yang memiliki jaringan atau keterkaitan satu sama lain dan memilikitujuan untukmengeksploitasi korban demi keuntungan sepihak (pelaku). Sehingga dalam mengatasi kasus trafficking ini, pemerintah memiliki andil dan harus menentukan sikap tegas dalam menangani dan memberantas kasus trafficking. Dikarenakan hal ini sangat memerlukan penanganan yang serius, maka diperlukan sebuah model untuk menangani korban trafficking yang komprehensif.

Model Penanganan Korban Trafficking sangat diperlukan untuk menangani sekaligus mengevaluasi dan memperbaiki sistem untuk kasus penanganan korban trafficking yang marak terjadi di Indonesia. Pembuatan model ini dilakukan dalam rangka menciptakan Keadilan dan Kesetaraan gender yang merupakan prinsipprinsip mendasar perlindungan Hak Asasi Manusia (HAM) sebagaimana diatur dalam Universal Declaration of Human Rights (UDHR) 1948, International Covenant on Civil and Political Rights (ICCPR) 1966, dan International Covenant on Economic, Social, and Cultural Rights (ICESCR) 1966. Sebagai negara peserta konvensi, sesuai Pasal 2 Konvensi Mengenai Penghapusan Segala Bentuk Diskiriminasi Terhadap Wanita (Convention on the Elimination of All Forms of Discrimination against WomenCEDAW), Indonesia wajib menghukum setiap bentuk diskriminasi dan berupaya untuk menghentikan segala bentuk kekerasan terhadap perempuan. $C E D A W$ juga menyarankan seluruh program dan aspek pembangunan harus mengakomodir upaya pence- 
gahan diskriminasi terhadap perempuan. Hal tersebut juga diperkuat oleh Komunitas Internasionalyang dituangkan dalam Millenium Development Goals (MDGs) mengenai kesetaraan dan keadilan gender.

Sebagai bukti keseriusan Indonesia dalam upaya menghapus kekerasan terhadap perempuan yang salah satunya adalah perdagangan perempuan (trafficking), beberapa produk hukum telah dibuat pada level nasional, antara lain:

1. UU No. 7 Tahun 1984 Mengenai Ratifikasi $C E D A W$.

2. Keppres No. 36 Tahun 1990 Mengenai Ratifikasi Konvensi PBB tentang Hak-Hak Anak.

3. Joint Decree 2002, yaitu Keput usan Bersama Pemerintah dalam Pelayanan Korban Penanganan Korban Trafficking.

4. Undang-Undang No.23 Tahun 2002 tentang Perlindungan Anak.

5. Undang-Undang No. 23 Tahun 2004 tentang Penghapusan Kekerasan dalam Rumah Tangga.

6. Undang-Undang No. 4 Tahun 2006 tentang Penyelenggaraan Kerjasama Korban KDRT.

7. Undang-Undang No. Tahun 2006 tentang Perlindungan Saksi dan Korban.

8. Undang-Undang No.21 Tahun 2007 tentang Pemberantasan Tindak Pidana Perdagangan Orang.
9. Inpres 9/2000 dan Kepmendagri 132 tahun 2003 tentang Pengarusutamaan Gender dalam Pembangunan Nasional.

10. Perda No.3/2008:Peraturan Daerah Provinsi Jawa Barat tentang Pencegahan dan Penanganan Korban Perdagangan Orang di Jawa Barat.

Permasalahan mengenai trafficking saat ini sudah menjadi permasalahan publik yang harus segera diatasi oleh pemerintah baik pusat maupun daerah, karena tanpa adanya tindakan yang dilakukan pemerintah dalam mengantisipasi dan menangani kasus perdagangan orang ini, dikhawatirkan akan terus memperpanjang deretan kasus trafficking. Dalam Kerangka Otonomi Daerah, Program Penanganan Trafficking juga merupakan Kewenangan Daerah. Daerah harus mampu mengimplementasikan kebijakan pusat terkait dengan program tersebut. Implementasi tersebut bisa berupa peraturan, kebijakan, dan program, bahkan model penanganan yang berkelanjutan.

Terkait hal tersebut, Pemerintah DaerahJabar,menunjukkankeseriusannya dalam upayamenghapus trafficking melalui Pengarusutamaan Gender (PuG) dalam Pembangunan. Hal ini terlihat dari kebijakan dan program yang dijalankan oleh Pemerintah Jabar seperti yang tercant um dalam Rencana Pembangunan Jangka Menengah Daerah (RPJMD). Hal tersebut juga menjadi kewenangan pemerintah 
daerah Kabupaten/Kota. Berdasarkan data Bareskim Markas Besar Polisi Republik Indonesia ${ }^{69}$, dalam kurun waktu 2005-2009, Jabar menduduki peringkat terat as kasus trafficking. Hal ini dapat terlihat dari data kasus dan korban yang terjadi di wilayah ini yang mencapai 794 kasus. Disusul kemudian Kalimantan Barat dengan 711 kasus dan Jawa Timur dengan 441 kasus. Adapun peringkat di bawahnya adalah Jawa Tengah dengan 404 kasus dan Nusa Tenggara Barat dengan 233 kasus. Selanjutnyadiketahuibahwadata persentase korban trafficking terhadap anak usia 0-17 tahun dan perempuan di Jabar terakhir yang terjadi tahun 2010 adalah 756 orang.

Kasus traficking di wilayah Hukum Polres Indramayu dalam tahun 2011 mengalami peningkatan. Satreskrim Polres Indramayu sendiri hingga September ini tengah menangani 8 kasus trafficking dengan jumlah tersangka sebanyak 14 orang dengan korban 19 orang. Kapolres Indramayu AKBP Rudi Setiawan, S.IK., M.H. melalui Kasat Reskrim Polres Indramayu AKP Rohadi, S.IK. didampingi Kasubag Humas AKP Wahyudin menjelaskan, selama 2011 ini memang ada peningkatan 2 kasus perdagangan orang. ${ }^{70}$ Dikatakan, korban trafficking rata-rata anak remaja putus sekolah yang dibawah umur berusia antara 15 dan 16 tahun. Umumnya para korban trafficking mengaku tergiur ajakan para cukong karena alasan ekonomi. Mereka juga mengaku, tawaran yang diberikan pada saat itu untuk bekerja di rumah makan atau restoran, namun dalam kenyataannya ternyata mereka diperkerjakan di cafe dan tempattempat prostitusi.

Berdasarkan latar belakang tersebut jelas kiranya perlu upaya penanganan korban trafficking secara integritas dengan menganalisis kebijakan-kebijakan PuG dan penelurusan di lapangan untuk evaluasi, perbaikan sistem, dan penguatan advokasi penghapusan terhadap kasus-kasus penanganan korban trafficking terutama kasus trafficking yang terjadi di Provinsi Jabar, khususnyadiKabupaten Indramayu.

\section{LANDASAN LITERATUR}

Menurut Pasal 1 ayat 8 Peraturan Daerah (Perda) Provinsi Jawa Barat No. 3 Tahun 2008 tentang Pencegahan dan Penanganan Korban Perdagangan Orang di Provinsi Jawa Barat, yang dimaksud dengan perdagangan orang adalah sebagai:

“...tindakan perekrutan, pengang-

69 Dikutip dari www.Seputar-Indonesia.com

70 Selengkapnya dapat dibaca pada mediaonline.com (24 September 2011). 
kutan, penampungan, pengiriman ataupenerimaanseseorangdengan ancaman kekerasan, penggunaan kekerasan, penculikan, penyekapan, pemalsuan, penipuan, penyalahgunaan kekuasaan atau posisi rentan, penjeratan utang atau memberi bayaran atau manfaat, sehingga memperoleh persetujuan dariorangyangmemegang kendali atas orang lain tersebut, baik yang dilakukan di dalam negara maupun ant arnegara, untuktujuan dieksploitasi at au mengakibatkan orang tereksploitasi."

Protokol PBB bidang Pencegahan Perdagangan Orang terhadap Manusia, terutama perempuan dan anak mendefinisikan trafficking sebagai berikut $^{71}$ :

“... perekrutan, pengiriman, pemindahan, penampungan, atau penerimaan seseorang, dengan ancaman atau penggunaan kekerasan atau bentuk-bentuk lain dari pemaksaan, penculikan, penipuan, kebohongan atau penyalahgunaan kekuasaan atau posisi rentan atau memberi atau menerima pembayaran atau memperoleh keuntungan agar dapat memperoleh persetujuan dari seseorang yang berkuasa atas orang lain untuk tujuan eksploitasi. Eksploitasi termasuk - paling tidak - eksploitasi untuk melacurkan orang lain atau bentuk-bentuk lain dari eksploitasi seksual, kerja atau pelayanan paksa, perbudakan atau praktek-praktek serupa perbudakan, penghambaan atau pengambilan organ tubuh.“

Berdasarkan definisi di atas terdapat beberapa istilah yang digunakan dalam praktek trafficking. Berikut adalah istilah dan penjelasannya $^{72}$, antara lain:

1. Perekrutan.Kata perekrutan tidak hanya merujuk pada perekrutan untuk bermigrasi dari daerah/ negara asal melalui janji-janji akan diberikannya pekerjaan dengan upah tinggi. Kata tersebut dapat pula merujuk pada para korban yang melakukan perpindahan tanpa dijanjikan untuk mendapatkan pekerjaan tetapi kemudian direkrut dengan cara ditipu, dibohongi, atau dipaksa di negara/daerah tujuan. Hubungan yang ada seringkali dapat dilihat pada cara orang tersebut direkrut di daerah/negara asalnya, lalu dipindahkan dan dieksploitasi di tempat tujuan.

2. Pengiriman (di dalam negara dan antarlintas batas negara). Sebuah kasus dikatakan sebagai kasus trafficking apabila korban

71 International Organization for Migration (IOM), 2005. Pemulangan dan Reintegrasi Korban Perdagangan Orang (Model Adendum). Jakarta. Hlm. 1.

72 Ibid, hlm 5-8 
dikirimkan ke tempat dimana ia terisolasi secara fisik dan tidak memahami bahasa dan budaya setempat, tidak mendapat hak at as indentitasnya yang sah serta tidak adanya akses untuk mendapatkan keadilan. Para migran dapat pula dilihat sebagi korban trafficking tanpa harus melihat mereka memasuki sebuah negara secara legal atau tidak, karena bukti yang diperlukan dapat terlihat dari kondisi pengiriman mereka dan/ atau kejadian-kejadian setelah proses pengiriman itu, misalnya eksploitasi yang terjadi.

3. Pemindahan, penampungan, dan penerimaan. Pelaku perdagangan orang (traffickers) memindahkan, menampung, dan/atau menerima korban-korban trafficking pada saat mengirimkan korban-korban tersebut dari tempat asal mereka ke tempat tujuan.

4. Pemaksaansecarafisik. Seseorang disebut dipaksa bila terikat dengan kekuatan fisik. Seseorang mungkin juga dipaksa untuk menurut dan bertentangan dengan keinginannya sendiri dengan cara lain, contohnya diiming-imingi sesuatu.

5. Penculikan. Seseorang dikatakan diculik bila diambil secara tidak sah dengan kekuatan atau melalui penipuan.

6. Penipuan. Seseorang telah ditipu jika ia menerima informasi yang salah atau kurang lengkap yang sengaja dilakukan oleh pelaku trafficking untuk kemudian disa- lahgunakan. Korban trafficking ditipu untuk masuk pada situasi kerentanannya.

7. Penyalahgunaan/penyiksaan. Seseorang dikatakan telah disalahgunakan secara disiksa jika orang tersebut berada dalam posisi rentannya dan tidak memiliki pilihan apapun selain tunduk kepada/menerima perlakuan tersebut kepadanya. Penyalahgunaan kekuasaan melibatkan situasi ketergantungan dimana seseorang yang memiliki kekuasaan atas orang lain tidak mengakui hak-hak dari orang-orang yang bergantung kepadanya.

8. Eksploitasi. Yaitu, mengambil keuntungan dari seseorang untuk tujuan dan kepentingan pribadi.

9. Prostitusi/Pelacuran. Perempuan dan anak memasuki dunia prostitusi dalam tiga cara yang berbeda, yaitu sukarela, jeratan hutang, dan ketidaksukarelaan.

10. Eksploitasi seksual, merupakan produksibarang-barangpornografi sebagai akibat dariketiadaan pilihan terhadap ancaman, penipuan, penyalahgunaan kekuasaan, jeratan hutang, atau pemalsuan.

11. Kerja Paksa. Seluruh jenis pekerjaan atau pelayanan yang didapatkan dari siapapun yang berada di bawah tekanan hukuman dan yang dilakukan bukan karena melakukannya secara sukarela.

12. Jeratan Hutang, adalah pada saat tenaga/layanan seseorang diperlukan sebagai cara pembayaran sebuah pinjaman/hutang. 
13. Perbudakan, adalah status atau kondisi dimana seseorang menjalankan segala hak penguasaannya atas orang lain.

14. Penghambaan. Banyak perempuan yang menjadi korban trafficking tidak sepenuhnya berada pada situasi kerja paksa atau perbudakan tapi mengarah pada penghambaan.

Terdapat beberapa bentuk perdagangan orang ${ }^{73}$ yang terjadi pada perempuan dan anak-anak:

1. Kerja Paksa Seks dan Eksploitasi Seks. Dalam banyak kasus, perempuan dan anak-anak dijanjikan pekerja sebagai buruh migran, PRT, pekerja restoran, penjaga toko, atau pekerjaanpekerjaan tanpa keahlian, tetapi kemudian dipaksa bekerja pada industri seks tetapi mereka ditipu dengan kondisi-kondisi kerja dan mereka dikekang di bawah paksaan dan tidak diperbolehkan menolak bekerja.

2. Pembantu Rumah Tangga (PRT), baik yang di luar negeri maupun yang di Indonesia berada dalam kondisi kerja yang sewenangwenang termasuk: jam kerjawajib yang panjang, penyekapan legal, upah yang tidak dibayar atau yang dikurangi, kerja karena jeratan hutang, penyiksaan fisik ataupun psikologis, penyerangan seksual, tidak diberi makan atau kurang makanan, dan tidak boleh menjalankan agamanya atau diperintah untuk melanggar agamanya. Beberapa majikan dan agen menyita paspor dan dokumen lain untuk memastikan para pembantu tersebut tidak mencoba melarikan diri.

3. Bentuk lain dari Kerja Migran. Meskipun banyak orang Indonesia yangbermigrasisebagai PRT, yang lainnya dijanjikan mendapatkan pekerjaan yang tidak memerlukan keahlian, seperti di pabrik, restoran, industri cottage, atau toko kecil.

4. Penari,Penghibur, danPertukaran Budaya-terutama di luar negeri. Perempuan dan anak perempuan dijanjikan bekerja sebagai penari duta budaya, penyanyi, atau penghibur di negara asing. Pada saat kedatangannya, banyak dari perempuan ini dipaksa untuk bekerja di industri seks atau pada pekerjaan dengan kondisi mirip perbudakan.

5. Pengantin pesanan-terutama di luar negeri. Beberapa perempuan dan anak perempuan yang bermigrasi sebagai istri dari orang berkebangsaan asing, telah ditipu dengan perkawinan.

73 Bentuk-bentuk Perdaganan Orang Manusia dalam www.stoptrafficking.or. 
6. Beberapa Bentuk Buruh/Pekerja Anak-terutama di Indonesia. Beberapa (tidak semua) anak yang berada di jalanan untuk mengemis, mencari ikan di lepas pantai seperti jermal, dan bekerja di perkebunan telah diperdagangkan ke dalam situasi yang mereka hadapi saat ini.

7. Trafficking/penjualan bayibaik di luar negeri maupun di Indonesia. Beberapa buruh migran Indonesia/TKI ditipu dengan perkawinan palsu saat di luar negeri dan kemudian mereka dipaksa untuk menyerahkan bayinya untuk diadopsi ilegal.

Secaraumum ${ }^{74}$ dapat diidentifikasi bahwa faktor-faktor yang mendorong terjadinya trafficking pada perempuan dan anak, antara lain disebabkan oleh:

1. Kemiskinan. Menurut data BPS adanya kecenderungan jumlah penduduk miskin meningkat dari 11,3\% pada tahun 1996 menjadi $23,4 \%$ pada tahun 1999 , walaupun berangsur-angsur telah turun kembali menjadi 17,6 \% tahun 2002.

2. Ketenagakerjaan. Sejak krisis ekonomi tahun 1998, angka partisipasi anakbekerjacenderung pula terus meningkat dari 1,8 juta pada akhir tahun 1999 menjadi 2,1 juta pada tahun 2000 .
3. Pendidikan. Survei Sosial Ekonomi Nasional (Susenas) 2000 melaporkan bahwa 34,0\% penduduk Indonesia berumur 10 tahun ke atas belum/tidak tamat SD/tidak pernah sekolah, 32,4\% tamat SD dan hanya $15 \%$ tamat SLTP. Menurut laporan BPS tahun 2000 terdapat $14 \%$ anak usia $7-12$ dan 24\% anak usia 13-15 tahun tidak melanjutkan pendidikan ke SLTP karena alasan tidak mampu dalam pembiayaan.

4. Migrasi. Menurut KOPBUMI (Konsorsium Pembela Buruh Migran di Indonesia), sepanjang tahun 2001 penempatan buruh migran ke luar negeri mencapai sekurang-kurangnya $\quad 74.616$ orang telah menjadi korban dari proses trafficking.

5. Kondisi Keluarga. Karena pendidikan rendah, keterbatasan kesempatan, ketidaktahuan akan hak, keterbatasan informasi kemiskinan, dan gaya hidup konsumtif antara lain faktor yang merupakan titik lemah ketahanan keluarga.

6. Sosial budaya. Anak sekolah merupakan hak milik yang dapat diperlakukan sekehendak orangtuanya, ketidakadilan jender atau posisi perempuan yang dianggap lebih rendah masih tumbuh di tengah kehidupan sebagian masyarakat Indonesia.

74 Termaktub dalam Keputusan Presiden No. 88 Tahun 2002. 
7. Media Massa, masih belum memberikan perhatian penuh terhadap berita dan informasi yang utuh dan lengkap tentang trafficking,danbelummemberikan kontribusi yang optimal pula dalam upaya pencegahan maupun penghapusannya. Bahkan tidak sedikit justru seringkali memberitakan yang kurang mendidik dan bersifat pornografis yang mendorong menguatnya kegiatan trafficking dan kejahatan susila lainnya.

Maksud dari pencegahan dan penanganan korban trafficking adalah untuk mensinergikan kebijakan pemerintah daerah dan kebijakan pemeritah kabupaten/kota dalam tata langkah operasional pencegahan dan penanganan korban trafficking di daerah secara komprehensif, efektif, dan efisien. Adapun tujuannya, adalah untuk(1)Mencegah sejak dinitindakan trafficking, (2) Memberikan perlindungan terhadap orang dari eksploitasi dan perbudakan manusia, Menyelamatkan dan merehabilitasi korban trafficking, serta (4) Memberdayakan pendidikan dan perekonomian korban trafficking beserta keluarganya. Sedangkan, sasarannya meliputi (1) Korban trafficking, (2) Keluarga korban, (3) Masyarakat di lingkungan korban, (4) Organisasi Sosial, LSM, dunia usaha, institusi pendidikan formal, dan lembaga pengiriman tenaga kerja; serta (5) Institusi Pemerintah Daerah, Pemerintah Kabupaten/Kota, Pemerintah
Kecamatan, dan Pemerintah Desa/ Kelurahan.

\section{METODOLOGI}

Dalam penelitian ini, peneliti melakukan analisis data dengan menggunakan pendekatan kualitatif dan metode deskriptif. Penelitian kualitatif merupakan sebuah proses penyelidikan yang didasarkan pada pemahaman atas perbedaan metodologis dalam menggali permasalahan manusia dan sosial. Peneliti membangun sebuah kompleksitas, gambaran holistik, menganalisis kata-kata, melaporkan informasi-informasi yang terperinci dan mengarahkan studi dalam kondisi yang umum atau lazim. Selanjutnya penelitian ini mempunyai rancangan penelitian kualitatif jenis studi kasus (case study) berperspektif gender. Metode Studi Kasus, yaitu penelitian yang menitikberatkan pada kasus spesifik secara utuh program penanganan korban trafficking yang dianalisisdenganpendekatankualitatif. Pendekatankualitatifsengajadilakukan guna memperoleh kualitas kehidupan yang berkaitan dengan pola pikir, pandangan, kesan, dan perasaan subyek penelitian.

Pengujian data dilakukan dengan teknik triangulasi, yaitu data tersebut selalu dikonfirmasikan secara timbalbalik dengan metode, teori, dan data atau pendapat para ahli atau berbagai sumber dari subyek penelitian. Sehingga, hasil dari pengujian tersebut 
selalu melalui diskusi intersubyektif, agar diperoleh data yang obyektif. Data primer yang diperoleh dianalisis dengan cara pemahaman atau verstehen, yaitu dengan cara mengungkapkan makna dan pengertian dari data tersebut baik secara tekstual maupun kontekstual. Data tersebut dikaji guna dipahami kaitannya dengan berbagai aspek yang akan menjelaskan rogram penanganan korban trafficking. Analisis data untuk memetakan isu permasalahan program penanganan korban trafficking dan permasalahan gender serta untuk mereformulasi kebijakan/program yang responsif gender, peneliti menggunakan alat analisis PROBA. ${ }^{75}$ Atas dasar itu, kemudian, peneliti menyusun model program penanganan korban trafficking.

\section{HASIL PENELITIAN DAN PEMBAHASAN}

\section{Lembar Kerja PROBA}

Di bawah ini adalah lembar kerja (LK) PROBA yang diperoleh dari masing-masing institusi/LSM dan disajikan dalam bentuk tabel.

Berdasarkan data pada tabel tersebut (yang bersumber dari PPA POLRES Indramayu), maka dapat diketahui, bahwa dalam kurun tiga tahun (2009-2011), kasus kekerasan trafficking di wilayah hukum Indramayu lebih banyak menimpa korban perempuan dewasa, yaitu sebanyak 17 orang, dan anak-anak ${ }^{76}$, yaitu sebanyak 16 orang. Adapun korban-korban tersebut berasal dari wilayah Indramayu (data terlampir).

Tabel 1 Data Kuantitatif Menurut Jenis Kelamin Kasus-Kasus Trafficking (LKA)

\begin{tabular}{|c|l|l|l|l|}
\hline No. & \multicolumn{1}{|c|}{ Informan } & \multicolumn{1}{|c|}{ Data } & \multicolumn{1}{c|}{ Sumber Data } & \multicolumn{1}{c|}{ Korban KBG } \\
\hline 1 & \multicolumn{1}{|c|}{2} & \multicolumn{1}{c|}{4} & \multicolumn{1}{c|}{5} \\
\hline 1 & $\begin{array}{l}\text { Ibu Sri } \\
\text { Kepala Bidang Pemberdayaan } \\
\text { dan Perlindungan Perempuan, } \\
\text { BPPKB Kab. Indramayu) }\end{array}$ & $\begin{array}{l}\text { (Data sama dengan data } \\
\text { dari Puan Amal Hayati } \\
\text { As-Sakienah) }\end{array}$ & $\begin{array}{l}\text { (Data sama dengan } \\
\text { data dari Puan } \\
\text { Amal Hayati As- } \\
\text { Sakienah) }\end{array}$ & $\begin{array}{l}\text { (Data sama } \\
\text { dengan data } \\
\text { dari Puan Amal } \\
\text { Hayati As- } \\
\text { Sakienah) }\end{array}$ \\
\hline
\end{tabular}

75 PROBA merupakan metode analisis gender yang disusun oleh Kementerian Pemberdayaan Perempuan dan Badan Koordinasi Keluarga Berencana Nasional (BKKBN) dan UNFPA. Teknik ini merupakan teknik yang terbaru, setelah sebelumnya menggunakan teknik Gender Analysis Pathway. Mengenai Teknik Analisis Gender dengan Metode PROBA (Problem Based Approach), Kementerian Pemberdayaan Perempuan, Jakarta, 2006.

76 Batasan usia untuk kategori anak adalah yang belum berusia 18 tahun (sumber: Perda Jawa Barat No. 3 Tahun 2008 Pasal 1 (9). 


\begin{tabular}{|c|c|c|c|c|}
\hline 2 & $\begin{array}{l}\text { Ibu Dwi Hartati } \\
\text { (Kepala Unit Perlindungan } \\
\text { Perempuan dan Anak, } \\
\text { POLRES Indramayu) }\end{array}$ & $\begin{array}{l}\text { Tahun } 2009=6 \text { kasus } \\
\text { Tahun } 2010=6 \text { kasus } \\
\text { Tahun } 2011=8 \text { kasus } \\
\text { (sampai oktober 2011). }\end{array}$ & $\begin{array}{l}\text { Unit Perlindungan } \\
\text { Perempuan dan } \\
\text { Anak, POLRES } \\
\text { Indramayu }\end{array}$ & $\begin{array}{l}\text { Dengan jumlah } \\
\text { korban }=7 \text { orang } \\
\text { ( } 6 \text { anak dan } \\
1 \text { perempuan } \\
\text { dewasa) } \\
\text { Dengan jumlah } \\
\text { korban }=9 \text { orang } \\
(1 \text { anak dan } 8 \\
\text { dewasa) } \\
\text { Dengan jumlah } \\
\text { korban = } 17 \\
\text { korban ( } 9 \text { anak } \\
\text { dan } 8 \text { dewasa) }\end{array}$ \\
\hline 3 & $\begin{array}{l}\text { Bapak Karman dan Ibu Sri } \\
\text { (Staf Dinas Sosial dan Tenaga } \\
\text { Kerja, Kab. Indramayu) }\end{array}$ & & & \\
\hline 4 & $\begin{array}{l}\text { Bapak Teten } \\
\text { (Kepala Bidang Sosial dan } \\
\text { Budaya, BAPEDA Kab. } \\
\text { Indramayu) }\end{array}$ & & & \\
\hline 5 & $\begin{array}{l}\text { Bapak Syamsul } \\
\text { (Pengurus Ponpes Puan Amal } \\
\text { Hayati As-Sakienah) }\end{array}$ & 1 kasus & $\begin{array}{l}\text { Laporan } \\
\text { Masyarakat }\end{array}$ & $\begin{array}{l}\text { Jumlah korban } 1 \\
\text { orang }\end{array}$ \\
\hline
\end{tabular}

Tabel 2 Analisis Penyebab Terjadinya Trafficking (LK-B)

\begin{tabular}{|c|c|c|c|c|c|c|c|c|c|}
\hline \multirow[b]{2}{*}{ No } & \multirow[b]{2}{*}{ Informan } & \multirow[b]{2}{*}{$\begin{array}{l}\text { Masalah/ } \\
\text { Kasus } \\
\text { Trafficking }\end{array}$} & \multicolumn{7}{|c|}{ Faktor Penyebab } \\
\hline & & & $\begin{array}{l}\text { Lingkungan } \\
\text { Sosial }\end{array}$ & $\begin{array}{c}\text { Pemahaman } \\
\text { Agama }\end{array}$ & $\begin{array}{l}\text { Adat } \\
\text { Istiadat/ } \\
\text { Budaya }\end{array}$ & Ekonomi & $\begin{array}{l}\text { Perundang- } \\
\text { undangan }\end{array}$ & Kebijakan & Lain-lain \\
\hline 1 & 2 & 3 & 4 & 5 & 6 & 7 & 8 & 9 & 10 \\
\hline 1 & $\begin{array}{l}\text { Ibu Sri } \\
\text { (Kepala Bidang } \\
\text { Pemberdayaan } \\
\text { dan } \\
\text { Perlindungan } \\
\text { Perempuan, } \\
\text { BPPKB Kab. } \\
\text { Indramayu) }\end{array}$ & $\begin{array}{l}\text { Banyak } \\
\text { tawaran- } \\
\text { tawaran dari } \\
\text { para trafficker } \\
\text { dengan } \\
\text { penghasilan } \\
\text { yang } \\
\text { menggiurkan }\end{array}$ & Mendukung & Kurang & & Masih Rendah & $\begin{array}{l}\text { Masih Lemah } \\
\text { Belum } \\
\text { maksimal } \\
\text { dilaksanakan }\end{array}$ & $\begin{array}{l}\text { Lebih } \\
\text { diperketat } \\
\text { lagi }\end{array}$ & \\
\hline 2 & $\begin{array}{l}\text { Ibu Dwi Hartati } \\
\text { (Kepala Unit } \\
\text { Perlindungan } \\
\text { Perempuan dan } \\
\text { Anak, POLRES } \\
\text { Indramayu) }\end{array}$ & & $\begin{array}{l}\text { Pola hidup } \\
\text { yang } \\
\text { konsumtif } \\
\text { Kurangnya } \\
\text { lapangan } \\
\text { pekerjaan }\end{array}$ & $\begin{array}{l}\text { Masih } \\
\text { kurangnya } \\
\text { pemahaman } \\
\text { masyara-kat } \\
\text { terhadap } \\
\text { agama }\end{array}$ & & $\begin{array}{l}\text { Adanya } \\
\text { permintaan } \\
\text { dari tempat } \\
\text { tujuan. } \\
\text { Masih } \\
\text { banyaknya } \\
\text { masyarakat } \\
\text { yang kurang } \\
\text { mampudari } \\
\text { segi perekono- } \\
\text { mian. }\end{array}$ & & & $\begin{array}{l}\text { Pendi- } \\
\text { dikan yang } \\
\text { masih } \\
\text { rendah }\end{array}$ \\
\hline 3 & $\begin{array}{l}\text { Bapak Karman } \\
\text { dan Ibu Sri } \\
\text { (Staf Dinas } \\
\text { Sosial dan } \\
\text { Tenaga Kerja, } \\
\text { Kab. Indramayu) }\end{array}$ & & & & & & & & \\
\hline
\end{tabular}




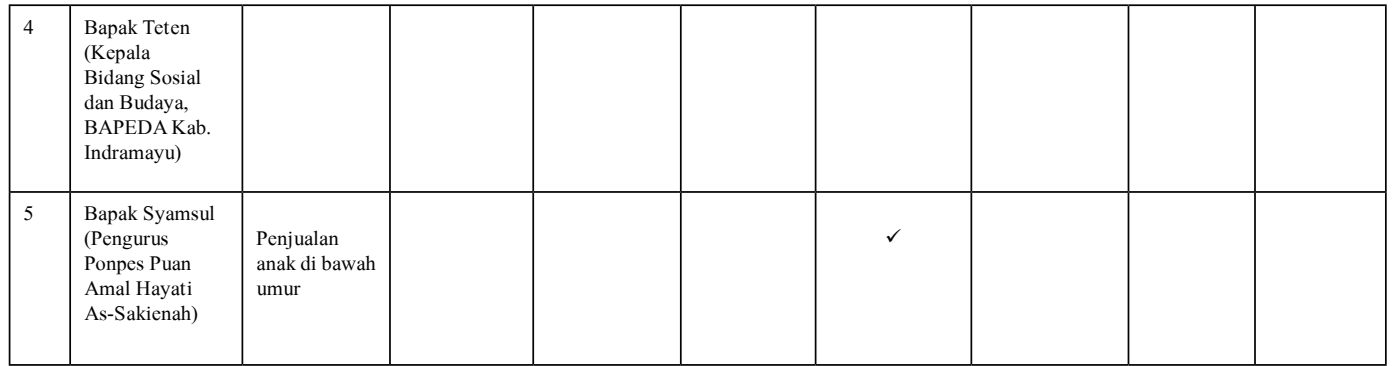

Berdasarkan data diatas maka dapat diketahui bahwa permasalahan trafficking yang terjadi di Indramayu adalah, dapat dikatakan, karena adanya faktor-faktor penyebabnya, antara lain dari segi: (1) Lingkungan/Sosial, (2)

Pemahaman Agama, (3) Ekonomi, (4) Perundang-undangan, (5) Kebijakan, dan (6) Pendidikan.

Tabel 3 Telaah Kebijakan/Program/Kegiatan (LK-C)

\begin{tabular}{|c|c|c|c|c|c|c|}
\hline No & Informan & $\begin{array}{l}\text { Masalah } \\
\text { Trafficking }\end{array}$ & $\begin{array}{c}\text { Kebijakan/ } \\
\text { Program/Kegiatan }\end{array}$ & Tujuan & $\begin{array}{c}\text { Netral/ } \\
\text { Bias/ } \\
\text { Responsif } \\
\text { Gender }\end{array}$ & Alasan \\
\hline 1 & 2 & 3 & 4 & 5 & 6 & 7 \\
\hline 1 & $\begin{array}{l}\text { Ibu Sri } \\
\text { (Kepala } \\
\text { Bidang } \\
\text { Pemberdayaan } \\
\text { dan } \\
\text { Perlindungan } \\
\text { Perempuan, } \\
\text { BPPKB Kab. } \\
\text { Indramayu) }\end{array}$ & $\begin{array}{l}\text { Pendidikan } \\
\text { rendah, } \\
\text { ekonomi } \\
\text { pas-pasan, } \\
\text { pengaruh } \\
\text { lingkungan, } \\
\text { rayuan dari } \\
\text { trafficker. } \\
\text { Kurangnya } \\
\text { pemahaman } \\
\text { masyarakat } \\
\text { terhadap } \\
\text { trafficking }\end{array}$ & $\begin{array}{l}\text { Pembentukan } \\
\text { P2TP2A }\end{array}$ & $\begin{array}{l}\text { - Sosialisasi } \\
\text { - TTPO } \\
\text { - Perlindungan } \\
\text { Anak } \\
\text { - Pornografi } \\
\\
\text { Guru bimbingan } \\
\text { konseling Siswa } \\
\text { SLTP dan SLTA }\end{array}$ & & \\
\hline 2 & $\begin{array}{l}\text { Ibu Dwi } \\
\text { Hartati } \\
\text { (Kepala Unit } \\
\text { Perlindungan } \\
\text { Perempuan } \\
\text { dan Anak, } \\
\text { POLRES } \\
\text { Indramayu) }\end{array}$ & & $\begin{array}{l}\text { 1. Sosialisasi UU } \\
\text { TPPO: } \\
\text { - Media elektronik } \\
\text { (Talkshow) } \\
\text { - Sekolah-sekolah } \\
\text { - Masyarakat } \\
\\
\text { 2. Pendidikan } \\
\text { Perkara Secara } \\
\text { profesional } \\
\text { dengan } \\
\text { menerapkan UU } \\
\text { TPPO }\end{array}$ & $\begin{array}{l}\text { Masyarakat } \\
\text { paham akan } \\
\text { bahaya } \\
\text { menjadi korban } \\
\text { trafficking } \\
\\
\text { Efek jera } \\
\text { bagi pelaku } \\
\text { trafficking }\end{array}$ & & $\begin{array}{l}\text { Kejadian } \\
\text { trafficking } \\
\text { meningkat }\end{array}$ \\
\hline
\end{tabular}




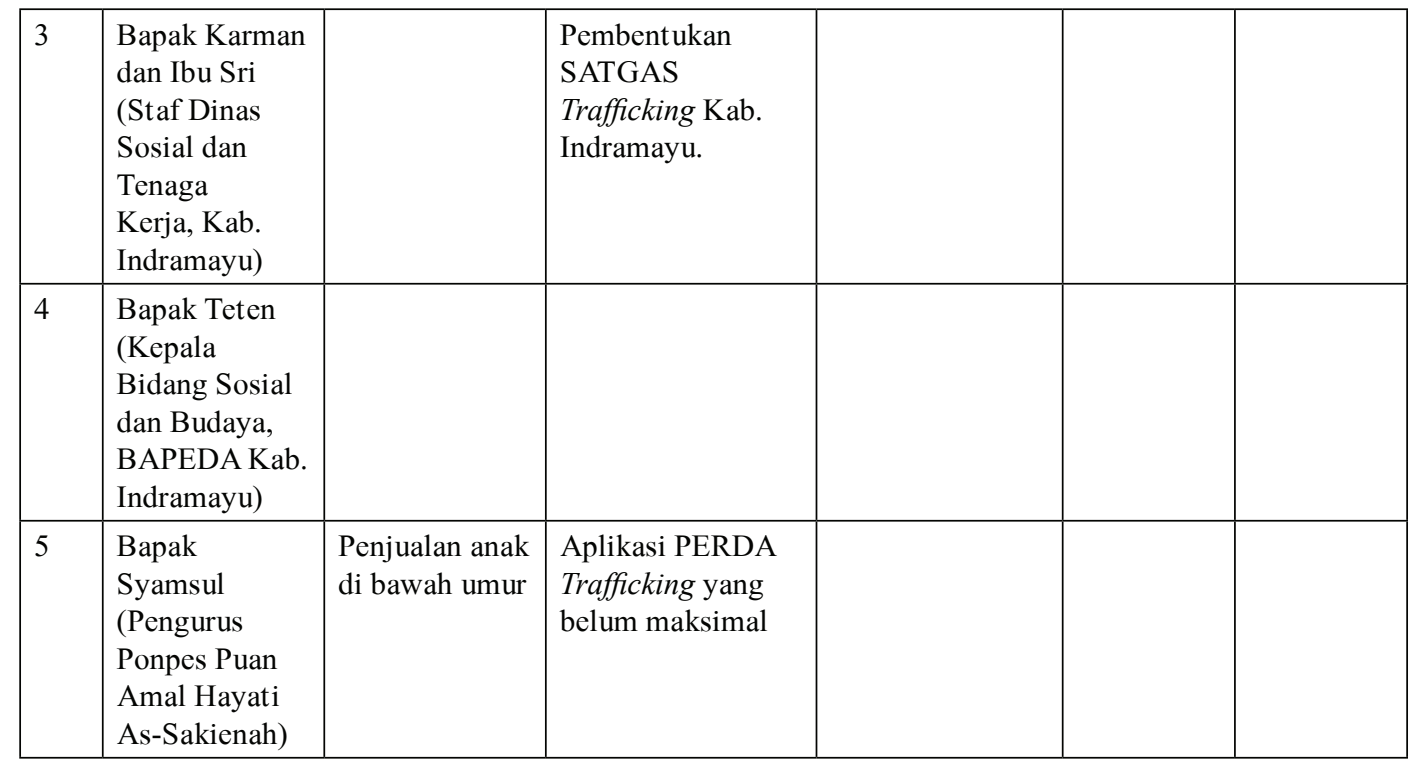

\section{Tabel 4 Identifikasi Masalah/Kasus-Kasus Trafficking (LK-D)}

\begin{tabular}{|c|c|c|c|}
\hline No. & Informan & $\begin{array}{l}\text { KEBIJAKAN/PROGRAM/KEGIATAN } \\
\text { YANG STRATEGIS } \\
\text { (mendukung penanganan korban } \\
\text { Trafficking) }\end{array}$ & Tujuan \\
\hline 1 & 2 & 3 & 4 \\
\hline 1 & $\begin{array}{l}\text { Ibu Sri } \\
\text { (Kepala Bidang } \\
\text { Pemberdayaan } \\
\text { dan Perlindungan } \\
\text { Perempuan, } \\
\text { BPPKB Kab. } \\
\text { Indramayu) }\end{array}$ & $\begin{array}{l}\text { Sosialisasi UU No. } 21 \text { Tahun } 2007 \\
\text { tentang TPPO } \\
\text { Sosialisai Perda no. } 3 \text { Tahun } 2008 \\
\text { Pengadaan buku tentang Trafficking }\end{array}$ & $\begin{array}{l}\text { Untuk mencegah terjadinya } \\
\text { korban trafficking }\end{array}$ \\
\hline 2 & $\begin{array}{l}\text { Ibu Dwi Hartati } \\
\text { (Kepala Unit } \\
\text { Perlindungan } \\
\text { Perempuan dan } \\
\text { Anak, POLRES } \\
\text { Indramayu) }\end{array}$ & $\begin{array}{l}\text { Sosialisai UU TPPO: } \\
\text { Media elektronik (Talkshow) } \\
\text { Siswa-siswa Sekolah } \\
\text { - Melalui konser musik } \\
\text { - Adanya duta trafficking kabupaten } \\
\text { Indramayu } \\
\text { Penyidikan perkara trafficking }\end{array}$ & $\begin{array}{l}\text { Masyarakat memahami } \\
\text { bahanya trafficking dan } \\
\text { mau melaporkan ke pihak } \\
\text { polisi apabila keluarganya } \\
\text { ada yang menjadi korban. } \\
\text { Sejak dini anak sekolah } \\
\text { harus mengetahui bahaya } \\
\text { trafficking sehingga anak- } \\
\text { anak usia remaja terhindar } \\
\text { sebagai korban. } \\
\text { Dengan menerapkan pasal- } \\
\text { pasal dalam UUTPPO } \\
\text { diharapkan memberikan } \\
\text { efek jera kepada para } \\
\text { pelaku TPPO }\end{array}$ \\
\hline
\end{tabular}




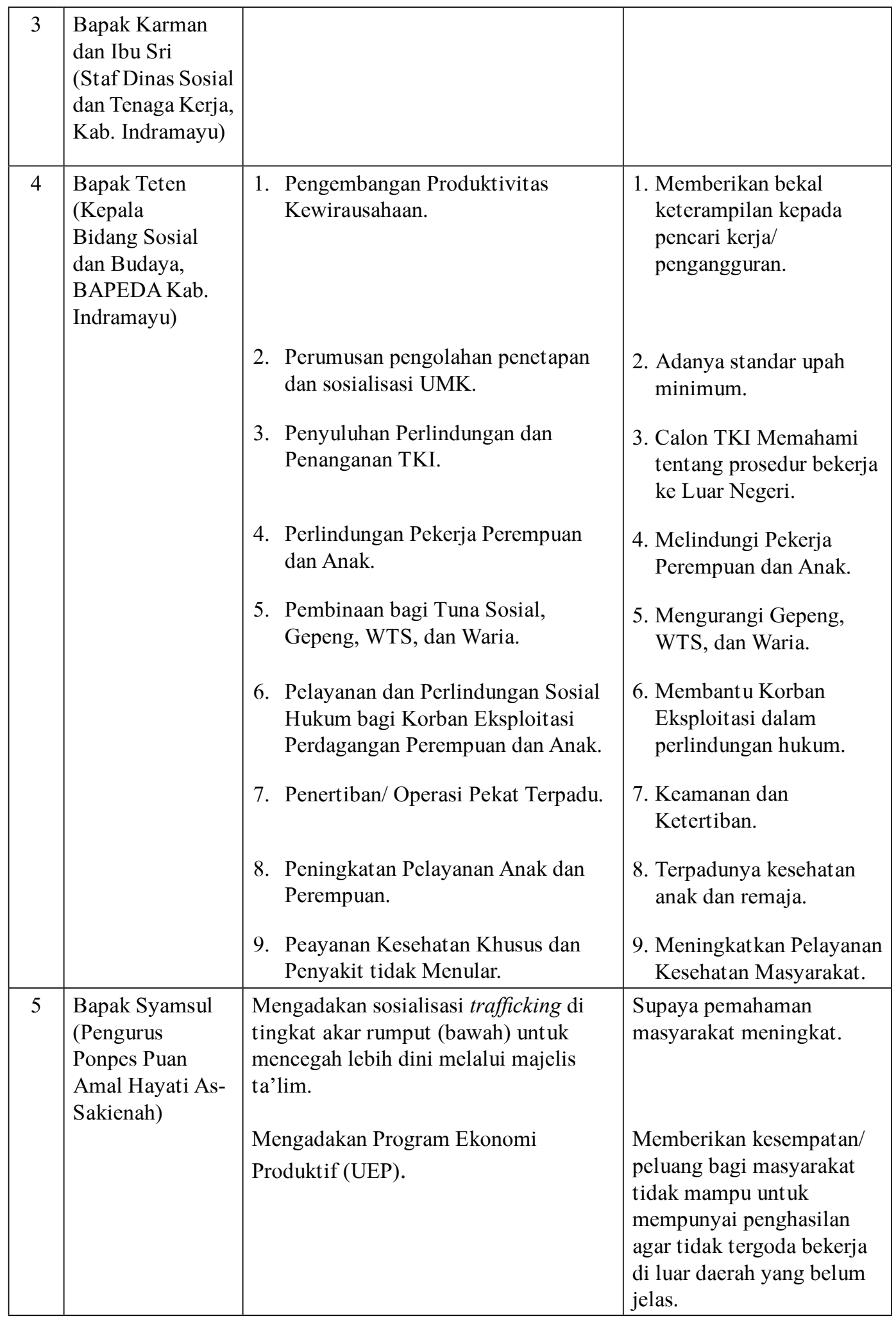




\section{Tabel 5 Kegiatan Intervensi dalam Setiap Program Penanganan \\ Kasus Trafficking \\ (LK-F)}

\begin{tabular}{|c|c|c|c|c|}
\hline Informan & Kegiatan & Target/Sasaran & Pelaksana & Waktu Pelaksanaan \\
\hline 1 & 2 & 3 & 4 & 5 \\
\hline $\begin{array}{l}\text { Ibu Sri } \\
\text { (Kepala Bidang } \\
\text { Pemberdayaan } \\
\text { dan Perlindungan } \\
\text { Perempuan, BPPKB } \\
\text { Kab. Indramayu) }\end{array}$ & $\begin{array}{l}\text { P2TP2A } \\
\text { Pelayanan dan perlindungan } \\
\text { hukum bagi korban } \\
\text { eksploi-tasi seks komersial } \\
\text { Perempuan dan Anak }\end{array}$ & $\begin{array}{l}\text { PNS dan Non PNS } \\
\text { Siswa SLTA } \\
\text { Korban Trafficking }\end{array}$ & $\begin{array}{l}\text { BPPKB } \\
\text { SATGAS } \\
\text { Trafficking }\end{array}$ & $\begin{array}{l}\text { 27-28 April } 2011 \\
\text { 28-29 Juli } 2011 \\
\text { Tentatif }\end{array}$ \\
\hline $\begin{array}{l}\text { Ibu Dwi Hartati } \\
\text { (Kepala Unit } \\
\text { Perlindungan } \\
\text { Perempuan dan Anak, } \\
\text { POLRES Indramayu) }\end{array}$ & Sosialisasi UUTPPO & $\begin{array}{l}\text {-Masyarakat } \\
\quad \text { (Orangtua) } \\
\text {-Siswa sekolah (Goes } \\
\quad \text { to School) }\end{array}$ & $\begin{array}{l}\text { - PPA } \\
\text { - Binmas }\end{array}$ & $\begin{array}{l}\text { - Tiap bulan } \\
\text { berkelanjutan } \\
\text { - Setelah } \\
\text { pelaksanaan ujian } \\
\text { semester }\end{array}$ \\
\hline $\begin{array}{l}\text { Bapak Karman dan } \\
\text { Ibu Sri } \\
\text { (Staf Dinas Sosial dan } \\
\text { Tenaga Kerja, Kab. } \\
\text { Indramayu) }\end{array}$ & & & & \\
\hline $\begin{array}{l}\text { Bapak Teten } \\
\text { (Kepala Bidang } \\
\text { Sosial dan Budaya, } \\
\text { BAPEDA Kab. } \\
\text { Indramayu) }\end{array}$ & $\begin{array}{l}\text { 1. Pengembangan } \\
\text { Produktivitas dan } \\
\text { Pelatihan Kewirausahaan } \\
\text { 2. Perumusan Pengolahan } \\
\text { Penetapan dan Sosialisasi } \\
\text { UMK } \\
\text { 3. Penyuluhan Perlindungan } \\
\text { dan Penanganan TKI } \\
\text { 4. Perlindungan Pekerja } \\
\text { Perempuan dan Anak } \\
\\
\text { 5. Pembinaan bagi Tuna } \\
\text { Sosial, Gepeng, WTS, } \\
\text { dan Waria } \\
\text { 6. Pelayanan dan } \\
\text { Perlindungan Sosial } \\
\text { Hukum bagi Korban } \\
\text { Eksploitasi Perdagangan } \\
\text { Pe-rempuan dan Anak } \\
\text { 7. Penertiban/ Operasi Pekat } \\
\text { Terpadu } \\
\text { 8. Peningkatan Pelayanan } \\
\text { Anak dan Perempuan } \\
\text { 9. Pelayanan Kesehatan } \\
\text { Khusus dan Penyakit } \\
\text { tidak Menular }\end{array}$ & $\begin{array}{l}\text { Pencari kerja/ } \\
\text { pengangguran } \\
\text { Perusahaan Swasta } \\
\text { Pengusaha dan CTKI } \\
\text { Pekerja Perempuan } \\
\text { dan Anak } \\
\text { Gepeng, WTS, dan } \\
\text { Waria } \\
\text { Korban Trafficking } \\
\text { Masyarakat } \\
\text { Anak dan Remaja } \\
\text { Anak SD/ MI }\end{array}$ & $\begin{array}{l}\text { Dinsosnakertrans } \\
\text { Dinsosnakertrans } \\
\text { Dinsosnakertrans } \\
\text { Dinsosnakertrans } \\
\text { Dinsosnakertrans } \\
\text { Dinsosnakertrans }\end{array}$ & $\begin{array}{l}2012 \\
2012 \\
2012 \\
2012 \\
2012 \\
2012 \\
2012 \\
2012 \\
2012\end{array}$ \\
\hline $\begin{array}{l}\text { Bapak Syamsul } \\
\text { (Pengurus Ponpes } \\
\text { Puan Amal Hayati } \\
\text { As-Sakienah) }\end{array}$ & Sosialisasi Anti Trafficking & Masyarakat pedesaan & Puan As-Sakienah & Setiap bulan \\
\hline
\end{tabular}




\section{ANALISIS LAPANGAN}

Kabupaten Indramayu merupakan wilayah di Jabar yang terletak di Bagian Utara (kawasan pantai utara) Jawa Barat. Persentase kasus traffiking di wilayah ini mencapai 54\%, disusul oleh Sukabumi 13\%, Cimahi 11\%, dan Garut $6 \%{ }^{77}$. Dengan demikian, Indramayu merupakan wilayah dengan kasus traffiking tertinggi.Walaupun begitu, hal tersebut harus dikaji dari dua kemungkinan. Pertama, tingginya angka kasus traffiking tersebut berdasarkan jumlah pelaporan terkait tindak kejahatan traffiking. Sebagaimana dikemukakan oleh Kanit PPA Polres Indramayu, Ibu Dwi Hartati, bahwa "kesadaran masyarakat untuk melaporkan traffiking cukup tinggi. Masyarakat sudah cukup terbuka saat ini". Hal yang sama dikatakan oleh Bapak SyamsuldariPuanHayatiAs-Sakienah. Sehingga, berdasarkan pernyataan keduanya, kemunculan tingginya angka kasus berdasarkan banyaknya laporan yang diterima pihak kepolisian atas dasar kesadaran masyarakat.

Kedua, tingginya angka kasus tersebut memang disebabkan dari banyaknya korban. Namun, sebagaimana dikemukakan oleh Bapak Karman dan Ibu Dwi, bahwa "banyak korban yang merupakan pendatang dari luar Indramayu yang mengaku sebagai warga Indramayu, sedangkan untuk korban yang berasal dari Indramayu asli, tidak terlalu banyak". Untuk mengetahui secara pasti, apakah kemungkinan pertama atau kedua yang membuat angka kasus traffiking di Indramayu besar, perlu diadakan survei lanjutan. Hanya saja, karena keterbatasan waktu survei, maka hal tersebut belum dapat dilakukan.Berikut ini merupakan data kasus terkait perlindungan perempuan di wilayah hukum Indramayu:

Tabel 6 Data Kasus Perlindungan Perempuan

\begin{tabular}{|c|c|c|c|c|c|c|c|c|c|c|c|c|c|c|c|c|}
\hline \multirow[b]{2}{*}{ Tahun } & \multicolumn{10}{|c|}{ Jenis Kekerasan } & \multicolumn{6}{|c|}{ Jenis Kasus } \\
\hline & $\frac{n}{\frac{n}{n}}$ & 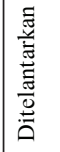 & 荺 & ڤ્ & 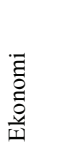 & 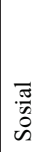 & 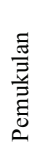 & 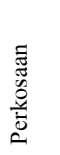 & $\begin{array}{l}\text { 足 } \\
\text { है } \\
\text { है }\end{array}$ & 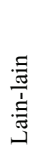 & $\underline{\underline{a}}$ & 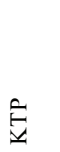 & $\overleftrightarrow{\underline{E}}$ & $\underline{\hat{\theta}}$ & $\begin{array}{l}\stackrel{x}{\omega} \\
\stackrel{0}{0} \\
\tilde{0}\end{array}$ & 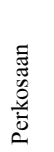 \\
\hline 2007 & 100 & 50 & 34 & 26 & 68 & 17 & 21 & 10 & 23 & 25 & 79 & 69 & 38 & 9 & 22 & 9 \\
\hline 2008 & 55 & 33 & 22 & 22 & 31 & 12 & 13 & 8 & 8 & 11 & 57 & 85 & 18 & 9 & 14 & 8 \\
\hline 2009 & 35 & 25 & 12 & 40 & 9 & 7 & 2 & 2 & 40 & 8 & 40 & 40 & 22 & 10 & 5 & 2 \\
\hline 2010 & 17 & 7 & 1 & 13 & 3 & 2 & 1 & 1 & 9 & 9 & 12 & 7 & 2 & 1 & 1 & 1 \\
\hline JUMLAH & 207 & 115 & 69 & 101 & 111 & 38 & 37 & 21 & 80 & 53 & 188 & 201 & 80 & 29 & 42 & 20 \\
\hline
\end{tabular}

Sumber: Women Crisis Center Puan Amal hayati As-Sakienah ${ }^{78}$.

77 Berdasarkan Datadari Jaringan Gerakan Perempuan Anti Trafiking Jawa Barat, 2009, dalam Sugianti, Anggi. 2011. Skripsi. Implementasi Kebijakan Pemerintah tentang Pencegahan dan Penanganan Korban Perdagangan Orang di Jawa Barat. Jatinangor: Universitas Padjadjaran, hlm. 64.

78 Dalam Bapeda, BPS Kab. Indramayu. Indramayu dalam Angka 2011, Hlm. 147. 
Jika melihat Tabel 6, maka trafficking menempati peringkat kelimadalam kasus kekerasan terhadap perempuan di wilayah hukum Indramayu.

\section{Faktor Penyebab Trafficking}

Jika melihat kembali pada Tabel 2, faktor-faktor penyebab terjadinya traffiking di Indramayu, antara lain:

Pendidikan. Tingkat putus sekolah di Indramayu.

Tabel 7 Tingkat Angka Putus Sekolah Tahun Ajaran 2009/2010 di Kabupaten Indramayu

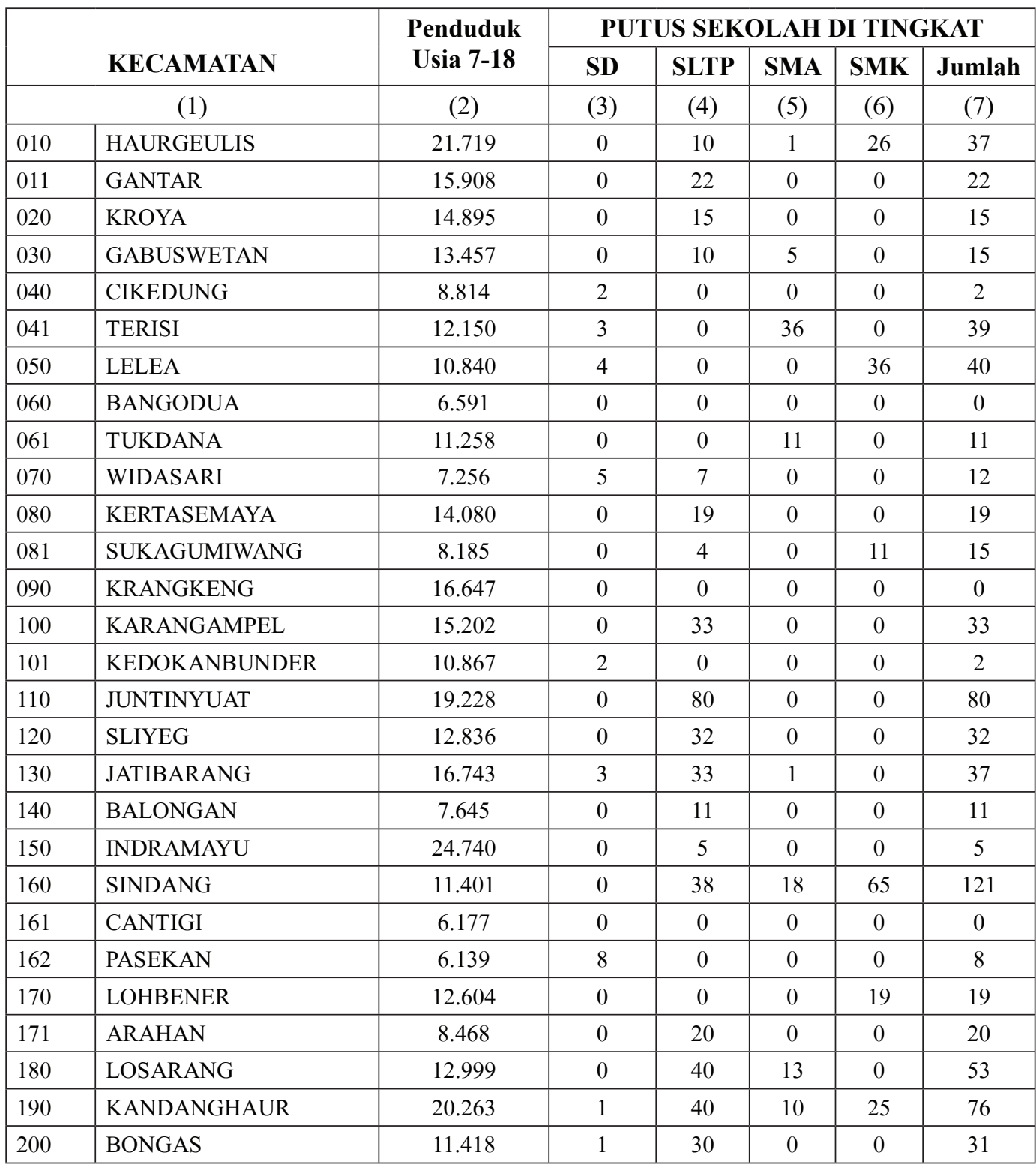




\begin{tabular}{|l|l|c|c|c|c|c|c|}
\hline 210 & ANJATAN & 19.891 & 0 & 45 & 0 & 0 & 45 \\
\hline 220 & SUKRA & 10.488 & 4 & 0 & 0 & 0 & 4 \\
\hline 221 & PATROL & 12.240 & 3 & 56 & 16 & 0 & 75 \\
\hline \multicolumn{2}{|c|}{ TAHUN 2009 /2010 } & $\mathbf{4 0 1 . 1 4 9}$ & $\mathbf{3 6}$ & $\mathbf{5 5 0}$ & $\mathbf{1 1 1}$ & $\mathbf{1 8 2}$ & $\mathbf{8 7 9}$ \\
\hline
\end{tabular}

Sumber: Dinas Pendidikan Kab. Indramayu ${ }^{79}$.

Sosial/Lingkungan. Hingga tahun 2008, terjadi beberapa masalah kesejahteraan sosial di wilayah Indramayu.
Adapun banyaknya masalah dapat dilihat pada pada Tabel 8:

Tabel 8 Masalah Kesejahteraan Sosialdi Indramayu

\begin{tabular}{|c|c|c|c|}
\hline Masalah & Jumlah & Masalah & Jumlah \\
\hline Anak balita terlantar & 2839 & Wanita korban kekerasan & 435 \\
\hline Anak terlantar & 6961 & Lanjut usia terlantar & 10210 \\
\hline Anak korban kekerasan & 336 & Lansia korban kekerasan & 5219 \\
\hline Anak nakal & 1133 & Penyandang cacat & 1920 \\
\hline Anak jalanan & 699 & Penyandang cacat eks penyakit & 2529 \\
\hline Anak cacat & 2874 & Tuna susila & 706 \\
\hline Wanita rawan sos-ek & 8686 & Pengemis & 834 \\
\hline Gelandangan & 422 & Keluarga bermasalah sosial & psikologis \\
\hline Keluarga yg tinggal di \\
rumah tidak layak huni
\end{tabular}

Sumber: Dinas Sosial dan Tenaga Kerja Kab. Indramayu ${ }^{80}$

79 Berdasarkan data dari Dinas Pendidikan dan Kebudayaan Kab. Indramayu tahun ajaran 2009/2010 dalamBapeda, BPS Kab. Indramayu. Indramayu dalam angka 2011, Hlm. 136 80 Ibid. 
BerdasarkanTabel 8, makaterlihat bahwa masalah terbanyak adalah masalah kemiskinan. Selain itu, kondisi lingkungan dimana mayoritas penduduk bekerja sebagai pekerja migran juga mendorong masyarakat lainnya untuk bekerja seperti itu.

1) Ekonomi. Permasalahan ekonomi juga menjadi faktor pendorong terjadinya traffiking ataupun kekerasan pada perempuan. Dari total 451.947 rumah tangga, terdapat 169.720 rumah tangga miskin ${ }^{81}$. Dengan kondisi perekonomian yang tidak memadai, mendorong seseorang untuk mencari pekerjaan. Dan seringkali, kondisi seperti inilah yang dimanfaatkan oleh trafficker untuk mencari korban namun dalam implementasinya masih lemah dan belum maksimal.

2) Agama. Masih kurangnya pemahaman terhadap agama. Sehingga, pemerintah mengeluarkan kebijakan mengenai kewajiban bagi para murid perempuan untuk menggunakan seragam panjang (berjilbab). Bagi murid SD diwajibkan mengikuti kegiatan madrasah.

3) Perundang-undangan. Menurut Ibu Sri (BPPKB Indramayu), walau sudah dibuat UU maupun Perda,
Adapun perundang-undangan yang digunakan dalam media sosialisasi trafficking di Indramayu, antara lain:

a) Perda Indramayu No. 14 Tahun 2005 tentang Pencegahan dan Pelarangan Traffikinguntuk Eksploitasi Seksual Komersial Anak di Kabupaten Indramayu.

b) UU No. 44 Tahun 2008 tentang Pornografi.

c) UU No. 21 Tahun 2007 tentang Pemberantasan Tindak Pidana Perdagangan Orang.

d) UU No. 23 Tahun 2002 tentang Perlindungan Anak.

4) Kebijakan. Menurut Ibu Sri (BPPKB Indramayu), kebijakan yang selama ini diterapkan oleh Pemerintah Indramayu harus diperketat lagi, harus lebih dipertegas lagi, baik dalam implementasinya maupun dalam sanksi yang akan diberikan jika dilanggar.

Terkait tindakan pencegahan dan penanganan trafficking di Indramayu, PemerintahIndramayutelahmelakukan beberapa upaya. Salah satunya adalah dengan membuat program-program terkait kekerasan trafficking. Adapun program tersebut dibagi kedalam dua

81 Op.,cit, Hlm. 114

142 CosmoGov, Vol.1 No.1, April 2015 
aktivitas, yakni Program Pencegahan dan Program Penanganan.

\section{Program Pencegahan}

Sebagai upaya pencegahan, Pemerintah Indramayu membuat beberapa program, antara lain:

\section{a) Sosialisasi}

Sasaran dari program sosialisasi ini adalah siswa/siswi SMA,SMK, dan Madrasah Aliyah, serta remaja ${ }^{82}$. Upaya sosialisasi yang dilaksanakan Pemerintah Indramayu ${ }^{83}$ dilakukan dengan berbagai macam cara, yakni penyuluhan ke sekolah-sekolah dan penyebaran pamflet/leaflet yang berisi tentang informasi terkait traffiking dan perlindungan perempuan. Adapun leaflet/pamflet/media sosialisasi yang digunakan Pemerintah Indramayu untuk bersosialisasi antara lain:

- Leaflet tentang trafficking $\equiv$ dikeluarkan oleh P2TP2A Indramayu;

- Sticker $\equiv$ mengenai hak anak dan perempuan;

- Buku saku bagi anggota Gugus Tugas Indonesia = oleh Kementerian Negara Pemberdayaan Perempuan, USAid, IOMc Indonesia;

- Panduan dalam mengembangkan perdapencegahan dan penanganan trafficking $\equiv$ oleh Kementerian Negara Pemberdayaan Perempuan, USAid, IOMc Indonesia;

- Leaflet tentang pencegahan trafficking $\equiv$ oleh BPPKB Jabar;

- Leaflet tentang KDRT $\equiv$ oleh BPPKB Jabar;

- Leaflet tentang pencegahan pornografi $\equiv$ oleh BPPKB Jabar;

- Leaflet tentang bullying = oleh Kementerian Negara Pemberdayaan Perempuan dan Perlindungan Anak Indonesia.

Namun, yang menjadi titik kelemahan dari sosialisasi yang dilakukan oleh Pemerintah Indramayu adalah sosialisasi masih dilakukan terpusat. Sebagaimana dikatakan Ibu Sri bahwa, "Sosialisasi sampai saat ini masih berlangsung di zona 1 , sebagian zona 2, sedangkan zona $3^{84}$ belum". Bahkan, dari total 31 kecamatan yang ada di Indramayu, baru 4 kecamatan

82 Sebagaimana dikemukakan oleh Ibu Sri selaku Kabid Pemberdayaan Perempuan, BPPKB Kab. Indramayu.

83 Pemerintah Indramayu yang dimaksud adalah instansi/lembaga yang memiliki keterkaitan dalam bidang perlindungan perempuan dan penanganan trafiking di Indramayu.

84 Dalam penyebaran informasi, wilayah Indramayu terbagi menjadi tiga zona, yakni zona 1, zona 2 , dan zona 3. Zona 1 meliputi daerah-daerah yang berada di sekitar ibukota kabupaten. Zona 2 meliputi daerah tengah di wilayah Indramayu. Sedangkan, zona 3 meliputi daerah-daerah yang berada di wilayah terluar Indramayu atau daerah yang berbatasan dengan Kabupaten lain. 
yang telah diberikan sosialisasi, yakni Bongas, Gabuswetan, Indramayu, dan Sliyeg ${ }^{85}$.

\section{b) Wajib Belajar di Madrasah}

Untuk memberikan pemahaman agama sejak dini, Pemerintah Daerah Indramayu mengeluarkan kebijakan dimana isi dari kebijakan tersebut mewajibkan seluruh siswa SD untuk mengikuti kegiatan madrasah ${ }^{86}$. Selain itu, adanya kewajiban bagi seluruh siswi untuk menggunakan seragam sekolah panjang, juga merupakan upaya untuk mencegah tindakan pornografi.

Selain program di atas terdapat pula beberapa program yang telah direncanakan, antara lain:

\section{1) UEP (Usaha Ekonomi}

Produktif). Program ini direncanakan akan dilaksanakan pada tahun 2012. Program ini dilakukan sebagai upaya agar masyarakat tidak mencari pekerjaan di luar wilayah Indramayu, Pemerintah Daerah Indramayu memberikan modal bagi masyarakat terpilih ${ }^{87}$ untuk dapat berwirausaha mandiri.
Adapun modal yang diberikan bukan dalam bentuk uang, melainkan waserda atau warung serba ada. Diharapkan, kegiatan ini dapat mengurangi minat masyarakat untuk merantau ke luar Indramayu untuk bekerja, dimana seringkali masyarakat tertipu saat mencari pekerjaan.

2) Pagelaran Musik (konser). Sebagai upaya sosialisasi mengenai bahaya traffiking, Polres Indramayu berencana untuk mengadakan pagelaran musik dimana di dalamnya akan dikampanyekan informasi mengenai bahaya traffiking. Adapun penggagas dari kegiatan ini adalah bidang PPA Polres Indramayu. Selain itu, dalam pelaksanaannya Polres Indramayu berencana untuk mengadakan kerjasama dengan beberapa pihak.

3) Dijadikannya materi traffiking sebagai kurikulum di sekolahsekolah. Mengingat bahaya traffiking dapat menjerat siapa saja, maka Dinas Pendidikan Indramayu bekerjasama dengan BPPKB Indramayu dan Polres Indramayu, menjadikan traffiking sebagai materi dalam kurikulum yang harus dipahami siswa/siswi.

85 Berdasarkan informasi yang diperoleh dari Bapak Karman dan Ibu Sri selaku staf Dinas Sosial Kab. Indramayu.

86 Sebagaimana dikemukakan Bapak Karman selaku staf dari Dinas Sosial Kab. Indramayu.

87 Masyarakat terpilih yang dimaksud adalah masyarakat dengan kondisi perekonomian menengah ke bawah dan memenuhi kriteria yang telah ditentukan oleh Pemerintah Indramayu. 


\section{Program Penanganan}

Dalam upaya penanganan, terdapat pula program-program berbasis pelayanan yang diberikan kepada korban. Adapun bentuk pelayanan yang diberikan kepada korban dapat dilihat pada tabel berikut: tersebut ke penampungan atau tempat yang lebih aman, untuk kemudian dilanjutkan dengan tindakan rehabilitasi .

- Rehabilitasi, merupakan suatu upaya untuk memulihkan kondisi korban trafficking. Lamanya

Tabel 9 Layanan terhadap kasus perlindungan perempuan:

\begin{tabular}{|c|c|c|c|c|c|c|c|c|c|c|c|}
\hline \multirow[b]{2}{*}{ Tahun } & \multicolumn{11}{|c|}{ Jenis Layanan } \\
\hline & 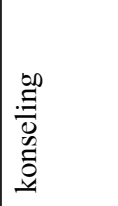 & 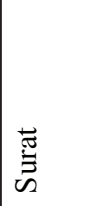 & 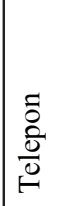 & 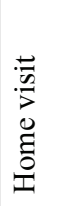 & 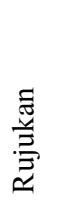 & 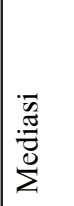 & 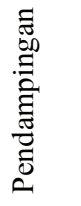 & 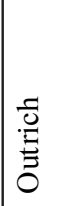 & $\begin{array}{l}\overrightarrow{\bar{v}} \\
\frac{\tilde{\Delta}}{\tilde{n}}\end{array}$ & 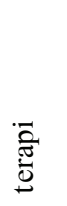 & 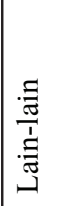 \\
\hline 2007 & 130 & 1 & 28 & 12 & 12 & 65 & 32 & 51 & 31 & 0 & 9 \\
\hline 2008 & 74 & 0 & 2 & 32 & 37 & 8 & 16 & 11 & 2 & 9 & 0 \\
\hline 2009 & 45 & 0 & 5 & 10 & 2 & 29 & 5 & 10 & 11 & 7 & 0 \\
\hline 2010 & 10 & 0 & 1 & 7 & 5 & 7 & 2 & 7 & 9 & 0 & 4 \\
\hline Jml & 259 & 1 & 36 & 61 & 56 & 109 & 55 & 79 & 53 & 16 & 13 \\
\hline
\end{tabular}

Sumber: Women Crisis Center Puan Amal hayati As-Sakienah ${ }^{88}$

Secara umum, penanganan terhadap korban trafficking meliputi tiga hal, yakni:

- Identifikasi, yaitu untuk mengidentifikasi orang-orang yang tereksploitasi sebagai korban trafficking, bukan mengidentifikasi pelaku trafficking ${ }^{89}$, lalu memindahkan orang/korban korban untuk direhabilitasi tergantung pada tingkat kondisi korban. Menurut IOM, apabila seseorang telah teridentifikasi sebagai korban trafficking, korban harus ditempatkan pada suatu penampungan atau rumah aman yang menyediakan lingkungan yang aman dan terlindung bagi pemulihan korban dan

88 Dalam Bapeda, BPS Kab. Indramayu. Indramayu dalam angka 2011, Hlm. 148.

89 Identifikasi t erhadap pelaku perdagangan orang dilakukan oleh pihak keamanan (Polisi) dimana asal kejadian berlangsung. Sebagai contoh, jika seorang pelaku melakukan tindak pidana, yaitu mengeksploitasi korban di wilayah Batam, maka proses pidana terhadap pelaku dilakukan di wilayah hukum Batam. 
penindaklanjutan prosesnya. $^{90}$ Penampungan atau rumah aman tersebut dikenal juga dengan sebutan shelter. Selama proses rehabilitasi berlangsung, korban untuk sementara waktu ditempatkan di shelter, baik shelter yang disediakan oleh Pemerintah Indramayu ataupun shelter-shelter yang berasal dari masyarakat (contohnya adalah Puan Amal Hayati As-Sakienah). Apabila korban membutuhkan pertolongan medis, maka layanan kesehatan dirujuk ke Rumah Sakit Bhayangkara Indramyu, bukan RSUD Indramayu. Hal ini dikarenakan pada saat proses hukum, jika dibutuhkan visum, pihak kepolisian lebih mudah merujuk ke Rumah Sakit Bhayangkara Indramayu.

- Reintegrasi, Tujuan dari suatu aktivitas reintegrasi sosial adalah untuk membantu korban trafficking untuk kembali berintegrasi dengan keluarga dan lingkungannya. Reintegrasi sosial sangat perlu dilakukan agar keluarga korban dan lingkungan di sekitar korban dapat menerima keberadaan korban kembali.
Dalam hal ini, BPPKB Indramayu dan Dinas Sosial memiliki peran penting dalam melaksanakan proses reintegrasi.

\section{SIMPULAN}

Kajian dan diskusi mengenai trafficking di Indonesia mulai bergulir awal tahun 2000, khususnya dipicu oleh munculnya kasus-kasus penyiksaan para perempuan Indonesia yang bekerja di luar negeri, baik sebagai pekerja rumah tangga (PRT) maupun yang terjerumus dalam pelacuran. Sebelumnya trafficking hanya dipahami terjadi dalam konteks pelacuran. Jabar adalah provinsi terpadat dan rumah bagi 16\% dari penduduk Indonesia. Setiap tahun, puluhan ribu perempuan, laki-laki, anak perempuan, dan anak laki-laki dari Jabar bermigrasi untuk mencari pekerjaan ke luar daerah dan ke luar negeri. Hal ini tentunya memiliki implikasi positif dan negatif, meski pada akhirnya kecenderungan implikasi negatif inilah menjadi lebih dominan seperti misalnya terjadinya tindak pidana trafficking. ${ }^{91}$

Jabar sendiri merupakan daerah

90 Dalam International Organization for Migration (IOM). 2005. Pemulangan dan Reintegrasi Korban Traffiking (Modul Adendum). Jakarta.

91 Definisi trafficking menurut Protokol PBB menyatakan secara jelas bahwa persetujuan korban tidak relevan jika korban adalah anak. Karena itu dalam semua kasus dimana anak dijadikan PSK harus dianggap trafficking kecuali jika mereka tidak dipindahkan dari rumahnya. Dalam kasus yang melibatkan korban orang dewasa, persetujuan tidak relevan jika ada unsur penipuan dan kekerasan. 
pengiriman utama buruh migran internasional khususnya terjadi dari Kabupaten Indramayu. Banyak dari mereka yang mengalami perlakuanperlakuan tidak adil dan kejahatan yang dilakukan oleh banyaknya perantara yang terlibat dalam proses migrasi (misalnya para calo, PJTKI, dan agen-agen penempatan di luar negeri) juga oleh para majikan mereka di negara tujuan. Berdasarkan hasil survey, diketahui bahwa permasalahan utama terjadinya trafficking adalah permasalahan tekanan ekonomi dan kesejahteraan. Permasalahan lainnya adalah rendahnya tingkat pendidikan dan minimnya pengetahuan masyarakat; situasi dan kondisi geografis daerah yang melemahkan ekonomi masyarakat; kondisi mental dan intelektual yang masih rendah; pembangunan yang tidak merata, penyalahgunaan wewenang, dan korupsi; kurang terampilnya para tenaga kerja migran; kurang profesionalnya pelaku penempatan buruh migran; serta terjadinya perselingkuhan antara pihak penguasa dan pengusaha.

Permasalahan lainnya juga diketahui bahwa trafficking disebabkan oleh keterbatasan informasi dan pengetahuan calon tenaga kerja mengenai sistem ketenagakerjaan (prosedur, job, negara tujuan), kurang adanya perlindungan yang diberikan oleh pemerintah Indonesia dan negara asing kepada tenaga kerja (larangan pemukulan, asuransi, pendidikan, kesehatan, pemerkosaan, dll); tidak efek- tifnya perangkat hukum di tingkat daerah(sepertiPerda) untukmelindungi tenaga kerja danmencegah terjadinya trafficking.

\section{SARAN}

Hal-hal yang menjadi perhatian bersama adalah:

1. Keberadaan dan kinerja Gugus Tugas baik di level Provinsi maupun Daerah sebaiknya lebih dimaksimalkan.

2. Perlu adanya kajian khusus untuk seluruh wilayah Kabupaten/ Kota di Jabar dalam kaitannya dengan aspek sosiologis dan budaya masyarakat. Karena kasus trafficking tidak semata-mata sebagai permasalahan ekonomi yang hanya diselesaikan dengan bentuk pemberdayaan ekonomi semata.

3. Penyelenggaraan Usaha Ekonomi Produktif perlu dievaluasi dikarenakan kecenderungannya ada beberapa yang tidak tepat sasaran dan tidak menutup kemungkinan dibuat programprogram pemberdayaan lanjutan.

4. Pentingnya pendataan ulang kasus-kasus trafficking yang tercat at diinstansi-instansiterkait dan strategis seperti Kepolisian, BPPKB Dinas Sosial, Dinas Tenaga Kerja, dan LSM agar penanganan kasus dapat lebih tepat sasaran. 


\section{DAFTAR PUSTAKA}

Giddens, Anthony, 1997. Sociology. Cambridge: Polity Press.

Sugianti, Anggi. 2011. Implementasi Kebijakan Pemerintah tentang Pencegahan dan Penanganan Korban Perdagangan Orang di Jawa Barat (Skripsi). Jatinangor: Universitas Padjadjaran.

\section{Lainnya (Alfabetis):}

Bapeda, BPS Kab. Indramayu, 2008. Indramayu dalam Angka.

Deklarasi Penghapusan Kekerasan terhadap Perempuan (Declaration on the Elimination of Violence against Women) Tahun 1993.

Depdagri. Pengarusutamaan Gender dalam Pembangunan Nasional.

Inpres 9/2000, 2001. Pengarusutamaan Gender dalam Pembangunan Nasional.
International Covenant on Civil and Political Rights (ICCPR) 1966.

International Covenant on Economic, Social, and Cultural Rights (ICESCR) 1966.

Kementerian Negara Pemberdayaan Perempuan RI, 2006, Mengenal Teknik Analisis Gender dengan Metode PROBA (Problem Based Approach)..

Kepmendagri 132 Tahun 2003.

Keppres No. 36 Tahun 1990 Mengenai Ratifikasi Konvensi PBB tentang Hak-Hak Anak Joint Decree 2002.

Universal Declaration of Human Rights (UDHR) 1948.

UUNo.7Tahun 1984tentangRatifikasi CEDAW.

UU No. 21 Tahun 2007 tentang Pemberantasan Tindak Pidana Perdagangan Orang. 